\title{
Ultrasound as tool for diagnosis of diseases of the reproductive tract bulls
}

\author{
K. C. Sousa ${ }^{1}$; S.T. Rolim Filho' ${ }^{1}$; H. F. L. Ribeiro' ${ }^{1}$; W.G. Vale \\ ${ }^{1}$ Universidade Federal Rural da Amazônia - UFRA - Instituto de Saúde e Produção Animal, Belém, Pará \\ ${ }^{2}$ Universidade Federal do Oeste do Pará - UFOPA - Instituto de Biodiversidade e Floresta, Santarém, Pará \\ Correspondência:wm.vale@hotmail.com
}

\begin{abstract}
The purpose of this study was to evaluate by ultrasound and breeding soundness examination (BSE) the major diseases affecting the reproductive tract of Nelore bulls, bred extensively in the state of Para, Brazil. Fifty-nine pure Nelore bulls were used, aged between 5 to 10 years, raised extensively in a commercial farm in the municipality of Paragominas, Pará state, Brazil. Scrotal circumference, testicular length and width were measured. Semen collection for evaluation of ejaculate volume, wave motion, motility, vigor, concentration and sperm pathologies was performed. Ultrasound examination was performed by equipment type Ultrasonic Transducer - CHISON/D600vet, linear transducers, where the frequency used was $5 \mathrm{MHz}$, being held two images of each testis, the longitudinal-lateral, lateral and transverse planes. The images were processed using the program Image J. The data were analyzed using the statistical program SAS (2000) and means were compared using Tukey's test $(p<0.05)$. Among the fifty-nine bulls evaluated, $39(66.1 \%)$ were classified as suitable for breeding and $20(33.8 \%)$ were classified as unsuitable. Throughout the use of ultrasonography changes as testicular degeneration one case $(1.6 \%)$, one of orchitis $(1.6 \%)$, one of hydrocele $(1.6 \%)$, nine of calcification $(15.2 \%)$ and two cysts in the testicular region parenchyma (3.3\%) were found. The average scrotal circumference was $38.6 \pm 2.4$ and $40.4 \pm 3.6 \mathrm{~cm}$ for the animals fit and unfit for reproduction categories respectively, observing statistical difference $(P<0.05)$. The average physical characteristics of semen for breeding animals was $74.2 \pm 18.8 \%$ for motility, $2.9 \pm 1.62 \%$ for wave motion, $3.2 \pm 1.08 \%$ for vigor, $4.7 \pm 2.58 \mathrm{~mL}$ for volume, $0.84 \pm 0.56 \times 106$ sperm $/ \mathrm{mm}^{3}$ concentration and $9.4 \pm 4.7 \%$ of total sperm pathologies. For the unfit animals data was $73.2 \pm 24.6 \%$ for motility, $2.8 \pm 1.78 \%$ for wave motion, $3.3 \pm 1.17$ vigor, $4.5 \pm 2.16 \mathrm{~mL}$ volume, $27 \pm 0.14 \%$ of total sperm pathologies and $0.85 \pm 0.51 \times 10^{6} \mathrm{sperm} / \mathrm{mm}^{3}$ for concentration. Statistical differences in the percentage of total sperm pathologies between fit and unfit animals was observed $(P<0.05)$. The mean pixel intensity of testicular parenchyma was 45.35 to 45.25 for fit for animals unfit animals, without any statistical difference $(P>0.05)$. Thus, it can be concluded that ultrasonography is an essential complementary tool in the diagnosis of reproductive disorders in animals subjected to BSE and its use should be recommended.
\end{abstract}

Key Words: Amazon, bovine, BSE, fertility, infertility, ultrasonography 


\section{INTRODUCTION}

The Brazilian cattle herd increased $1.6 \%$, totaling 212.8 million head in 2011, according to data released by the Brazilian Institute of Geography and Statistics (IBGE), where there was an increase North or Amazon region of $(2.7 \%)$, mainly in the states of Pará and Rondônia. Also according to the IBGE (2011), about $80 \%$ of the herd consists of animals of Zebu (Bos indicus), which are considered to be proven concerning hardiness and adaptation to the prevailing hot and humid environment of the Amazon region in Brazil. Among the breeds raised in the Brazilian Amazon region, it is highlighted the Nelore with $90 \%$ of the herds due its well adapted to the regional environment conditions, being the main breed used for the beef production animal system. Due to the increasing demand for higher animal genetics and the availability of methods for breeding soundness examination (BSE) the male semen picture, has been greatly increased as a factor of primordial responsibility during the BSE uses as well as to predict the fertility of males used as improved sires and also for the treatment of reproductive disorders. Thus, the already known methodology for measuring scrotal circumference have been aggregated as a routine tool for the selection of breeding, the use of testicular ultrasonography (Abdel-Razek and Ali, 2005), has also be incorporated as a important tool to find out testicular abnormalities not seen by the routine BSE performed.

Therefore the selection of the best animals in the post weaning stage and before to be used to serve female in a herd is an important aspect, which must be based on criteria that show not only the genetic potential, but also indicated its reproductive potential, early sexual maturity, libido and absence of genital tract abnormalities.

According Cardilli et al. (2010), the results of BSE, including the semen analysis are usually insufficient to obtain an accurate diagnosis when faced with an animal that fall in fertility.

That being so, there is a great prospect in the use of ultrasound for assessment of bulls before reaching puberty in order to predict the ability of sperm production when sexually mature as well as to detected the presence of anatomical abnormalities which are not possible to be detected by a clinical examination of the reproductive tract (Aravindakshan et al. 2000).

With the goal of providing a quick, safe and accurate diagnosis, ultrasonography constitutes an important method in animal breeding, allows to evaluate the internal reproductive organs with anatomical accuracy and noninvasive, harmless, safe and can be used routinely form. Thus the use of ultrasonography associated with the soundness examination shows to be of great importance, especially in sub clinical disorders (Ribadu and Nakao 1999).

According to Aravindakshan et al. (2000), when using ultrasound during BSE, can better detect differences in testicular consistency as well as to do a better relation to other aspects of semen quality and fertility of bulls used in breeding. Therefore, this author states that the analysis of intensity of the ultrasound image resolution can be a supplementary examination for interpretation of testicular disorders in breeding soundness evaluation.

Thus, the aim of this study was to evaluate the BSE in bulls used in natural mating in bovine production systems, using the ultrasonography to complement the diagnose of possible disturbs affecting the reproductive tract of Nelore bulls bred extensively in the 
northern region of Para state, Amazon, Brazil.

\section{MATERIAL AND METHODS}

The study was conducted in northern Pará state, Brazil, in the municipality of Patagonians, at Farms and Guarani Indian (2०59'51" South, $47^{\circ} 21^{\prime} 13^{\prime \prime}$ West), during the month of May 2012.

According to Köppen classification, the climate of the area of the experiment is hot and humid, divided into two seasons: rainy, between the months of December and May, and a less rainy season between June and November with an average rainfall around 2,200 $\mathrm{mm}$ annually. The maximum temperature varies between $29^{\circ} \mathrm{C}$ and $31^{\circ} \mathrm{C}$, with an average temperature of $26^{\circ} \mathrm{C}$ and a relative humidity presented between 78 to $93 \%$.

Fifty-nine Nelore bulls, ranging in age from five to ten years, all identified with earrings silicone and/or shod in leather fire (visible region) and documented in records of individual identification were used. The animals were raised extensively in cultivated pastures (Brachiaria brizantha, var. MG5), Mombasa and (Panicum maximum), and mineralization and water ad libitum. Animals were subjected to the health program which consisting in vaccination against Food and Mouth Diseases, Brucellosis and Rabies, yearly tested against Tuberculosis and dewormed twice a year. All males were kept allotted with fifty females in a breeding regime well-defined five months (December to April) and BSE routine examinations were performed before the breeding season. The animals were housed randomly into a corral and put in a squeeze for the clinical examination and semen collection. Data such as: identification of the animal, age and reproductive performances were entered into clinical record.

The penis and foreskin were checked by inspection. The testes and epididymis, for consistency, mobility and position, and normality of scrotum and spermatic cords were evaluated by palpation (CBRA, 1998).

The scrotal circumference was measured with the aid of a millimeter tape of $50 \mathrm{~cm}$ long, handle in the region of larger diameter of the testes involving both gonads and scrotal skin, and also measured in both length and width of each testis with a caliper.

The semen collection was performed using electro ejaculator with an average duration of three minutes with the aid of funnels, graduated collection tubes.

After semen collection, the ejaculate underwent physical evaluation: color, appearance, volume, wave motion, motility, vigor, concentration and morphological assessment (CBRA, 1998).

For the wave motion measurement, an aliquot of the ejaculate was taken with the aid of a micropipette $10 \mu \mathrm{L}$, and a small drop was put on a pre-heated glass slide and with the aid of an optical microscope at a $10 x$ magnification it was observed the motion wave form of sperm sorting them in a scale of 0 - 5 (VALE, 1997).

Motility was checked by an aliquot of the ejaculate, using a micropipette 10 $\mu \mathrm{L}$ and, and a small drop was put on a pre-heated glass slide $(26 \times 76 \mathrm{~mm})$ and a glass cover slip $(18 \times 18 \mathrm{~mm})$, with the aid of an optical microscope $20 x$ increase was observed in the percentage of sperm straight forward movement and vigor. It was also analyzed the effect, in magnification $20 x$, noting the quality of sperm motility displayed by being classified according to the scale: 1-5 (Kumar et al., 1988). Furthermore, aliquots $20 \mu \mathrm{l}$ of semen were placed in Ependorf nuncktubes vials with $2.0 \mathrm{ml}$ of 
saline buffered formalin in a dilution of 1:200 for the determination of semen concentration in the ejaculate evaluated through the haematimetric chamber of Neubauer type.

Semen smears were performed for analyze sperm morphology and subsequently stained by the method Cerovysky (Cerovysky, 1976) as well as a drop of semen was put in an Ependof nuncktubesor vials for further wet semen preparation. 200 cells were analyzed per stained and wet preparation slides through an optical microscope in immersion objective (100x magnification), where sperm with major and minor defects individually (Henry and Neves, 1998) were evaluated.

In addition, utrasonographic images were obtained through the ultrasound apparatus model Ultrasonic Transducer - CHISON/China, with the use of a trans-rectal linear probe 75L50EAV, multi - frequential 5.0/6.0/7.0 $\mathrm{MHz}$, where the frequency used was 5 $\mathrm{MHz}$ for all fifty-nine animals, being held two images of each testis plans longitudinal-lateral, lateral and transverse. In order to obtain a good quality image, contact gel was used (carboxy methyl cellulose), aiming to intensify the contact between the transducer and the scrotum structures.

The diagnosis of testicles images interpretations was measured by ultrasound values of grayscale ultrasound images were determined from ultrasound images of testicular parenchyma and expressed in units of pixel intensity. The full range of pixel intensities was defined by numerical values from 0 to 255 pixels, where the value 0 represents the anechoic black color and the value 255 pixels represents white hyperechoic. From these images, it was determined testicular echodensity, expressed in number of pixels/area. For this purpose it was used the Image $\mathrm{J}$ program which is a public domain software, based on an image processing program developed at the National Institutes of Health, in the United States, and that calculates the area and pixel value statistics of user-defined (Rasband, 2009).

The average of the pixel units of each testicle in both plans was obtained from five areas of approximately $1 \mathrm{~cm} 2$, selected randomly within the testicular parenchyma. Subsequently, the values of the average of both testicles testicular echodensity (Ecot) per animal was obtained.

To perform the statistical analysis, all data were tabulated in spreadsheets, with information supporting the determination of the parameters of the animals, for the development of a database. The mean and standard deviation of all the studied traits as pixel intensity (IP), scrotal circumference (SC), wave motion, motility, vigor, sperm concentration and total sperm pathologies were calculated using the SAS (2000) statistical program. For comparison between means, the animals were divided into two categories, fit and unfit for breeding according to the Breeding Soundness Examination (BSE). Means were compared by Tukey test with a significance level of $5 \%$.

\section{RESULTS AND DISCUSSION}

Whereas

biometrics, spermiogram and ultrasonography of fifty-nine bulls evaluated, 39 (66.1\%) were classified as suitable for breeding $20(33.8 \%)$ were classified as unfit for breeding according to clinical examination, biometric, seminal and ultrasonographic features.

Compared to 20 (34\%) animals deemed unfit for BSE were diagnosed by clinical examination and ultrasonography 14 (23\%) changes were testicular degeneration one (1.6\%), 
orchitis one (1.6\%), hydrocele one (1.6\%), calcification, $9(14.7 \%)$ and cyst located in the testicular region parequema two (3.2\%). The other 6 $(10.2 \%)$ were considered unfit because of problems related to the clinical examination (foot pad lesions and chronic balanoposthitis) and sperm pathologies being not accepted in the BSE.

The results found in this study were lower than the reported by Fonseca (2009), who worked with 6,586 Nellore in the state of Minas Gerais state, Brazil, obtaining satisfactory results of $87.3 \%$ for qualified animals and $12.7 \%$ for the unfit animals.

\section{Scrotal circumference (SC)}

The average SC was $38.6 \pm 2.4$ ) and $40.4 \pm 3.6 \mathrm{~cm}$ for the animals fit and unfit for reproduction categories respectively, observing statistical difference $(P<0.05)$. However, the average $\mathrm{SC}$ of animals classified as unfit was superior to animals considered able, and some animals of this group present changes as orchitis, hydrocele which increase scrotal circumference.

Valentine et al. (2002) working with bulls 20 months old Nelore males verified an average of $27.4 \mathrm{~cm} \mathrm{SC}$, lower than the results in this study to fit animals.

Lower results were also observed for SC by Viu et al. (2006) in Nelore bulls with 17 to 20 and 21 to 24 months of age $(30.0 \pm 3.0 \mathrm{~cm}$ and $33.2 \pm 2.8 \mathrm{~cm})$ respectively.

Therefore Fonseca (2009) worked with 6,586 bulls are extensively found a SC $36.4 \mathrm{~cm}$, lower than our study for both animals considered suitable for breeding and for animals deemed unfit for breeding result.

\section{Physical and morphological characteristics of semen}

The average physical characteristics of semen for breeding animals was $74.2 \pm 18.8 \%$ motility, $2.9 \pm 1.6$ wave motion, $3.2 \pm 1.0$ vigor, $4.7 \pm 2.5 \mathrm{~mL}$ volume, $9.4 \pm 4.7 \%$ and total sperm pathologies and $0.84 \pm 0.56 \times 10^{6}$ sperm cells $/ \mathrm{mm}^{3}$ for concentration. Even though for the unfit animals it was found $73.2 \pm 24.6 \%$ for motility, $2.8 \pm 1.7$ wave motion, $3.3 \pm 1.1$ vigor, $4.5 \pm 2.1 \mathrm{~mL}$ volume, $27.0 \pm 0.14 \%$ of total sperm pathologies and $0.85 \pm 0.51 \times 106$ sperm cells/mm3 concentration (Table 1). Statistical differences in the percentage of total sperm pathologies between fit and unfit $(P<0.05)$ animals was observed.

Table 1. Average seminal characteristics of fit and unfit for breeding Nelore bulls $b$ extensively in northeastem Pará state, Brazil.

\begin{tabular}{ccc} 
Ejaculate characteristics & \multicolumn{2}{c}{ Category } \\
\cline { 2 - 3 } & Fit & Unfit \\
\hline Motility (\%) & $74.2 \pm 18,8$ & $73.2 \pm 24,6$ \\
Wave montion $(1-5)$ & $2.9 \pm 1.6$ & $2.8 \pm 1.7$ \\
Vigor $(1-5)$ & $3.23 \pm 1.0$ & $3.3 \pm 1.1$ \\
Volume $(\mathrm{mL})$ & $4.75 \pm 2.5$ & $4.5 \pm 2.1$ \\
Sperm abnormalities & $9,4 \pm 4,7^{\mathrm{a}}$ & $27.0 \pm 14.1^{\mathrm{b}}$ \\
Concentration $\left(\times 10^{6}\right.$ sperm cells & $0.89 \pm 0.5$ & $0.85 \pm 0,5$ \\
\hline $\mathrm{mm}^{3}$ ) &
\end{tabular}

* Different letters in the same row differ statistically. ANOVA, Tukey's test $(P<0.05)$.

Either these differences in sperm pathologies can be explained by the presence of abnormalities found during the clinical and ultrasound examination of the animals belonging to the group as unfit for breeding likely testicular degeneration, hydrocele, orchitis and intratesticular cyst.

Santos et al. (2004) found mean motility $(74.5 \%)$ in Nelore bulls, between 7-10 years of age, similar to the present study in relation to the superior fit and unfit animals for breeding animals result.

On the other hand Fonseca (2009) worked with 6.586 bulls rised on field condition former scores sperm motility $73.37 \%$, lower than our study in relation to animals considered suitable for breeding and similar for animals 
deemed unfit for breeding outcome result.

Concerning concentration, Corrêa et al. (2006) studied 270 bulls of Tabapuã breed with two years old, and got an average of $0,337 \times 10^{6}$ sperm cells $/ \mathrm{mm}^{3}$ higher than the present study rather results for both animals considered suitable for breeding was $0.89 \times 10^{6}$ sperm cells $/ \mathrm{mm}^{3}$ as for animals deemed unfit for breeding and was $0.85 \times 106$ sperm cells $/ \mathrm{mm}^{3}$.

Fonseca (2009) found a total pathologies of $7.9 \%$ rather lower than the results of the present study for both group of animals considered fit and unfit for breeding.

Thus as can be seen in the literature these reproductive parameters for males in the Nelore breed can inferred, despite the existence of differences relating to motility parameters (\%).

Wave montion (1-5), vigor (1-5), volume $(\mathrm{mL})$ and sperm abnormalities and concentration in ejaculates, the variations found in the results of this study agree with those quotes, for both fit and unfit animals subjected to the breeding soundness examination reproductive (BSE).

\section{Testicular echogenicity}

The mean pixel intensity of testicular parenchyma found in the present study was 45.35 and 45.25 for the fit to the unfit animals (Table 2) animals, respectively without any statistical difference $(P>0.05)$.

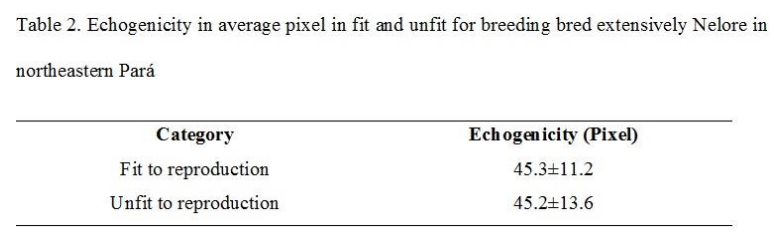

Probably due the echogenicity not ranged between the both group it is possible exist in animals considered unfit a normal echogenicity, being this animals classified in this category because they have other changes not detected by ultrasound exam.

The ultrasonographic pattern of the testicular parenchyma in nineteen young Nelore bulls, 10-18 months of age studied by Cardilli et al. (2012) proved to be homogeneous and moderate and it is was not found any difference $(P>0.05)$ between echogenicity of each testis, and the averages for the period from 10 to 18 months age were 29.55 and 29.19 pixel respectively, lower than the values of the present work.

Genital pathologies diagnosed throughout ultrasonography examination among the fifty-nine animals evaluated, 20 (34\%) were classified as unfit for breeding. One (1.7\%) animal was diagnosed with orchitis, one (1.7\%) and hydrocele, one (1.7\%) with testicular degeneration, two (3.4\%) in the presence of cysts and testicular parenchyma and $9(15.3 \%)$ in the presence of calcification. Some of these animals deemed unfit showed no change in clinical examination, with the only change detected by ultrasound evaluation or through the physical and morphological examination of semen.

Orchitis.

In the present study it was found one $(1.7 \%)$ case of orchitis. The ultrasound image (Figure 1) depicts the left testis $(A)$ and right $(B)$ of the same animal. The image of the left testis $(A)$ shows homogeneous high echogenicity feature of the testicular parenchyma and hyperechoic mediastinum, with normal echogenicity. Therefore the image of the right testis (B) shows testicular parenchyma with low echogenicity and hyperechoic spots with little education and moderate posterior acoustic shadowing.

Bumin et al. (2007) diagnosed by ultrasonography six (17.6\%) and sixteen $(47.0 \%)$ cases of unilateral and bilateral orchitis, respectively in dogs. In animals with unilateral orchitis testicular 
parenchyma showed heterogeneous feature, characterized by having the hypoechoic areas increased echogenicity in inflamed testicles, compared with the other (homogeneous), similar to those found in the present study. In animals with bilateral orchitis, testicular parenchyma showed heterogeneous structure with diffuse hyperechoic areas hypoechogenicity.

Other authors reported that in cases of orchitis, the testes are usually flacid and increased in size in the ultrasound pictures showing a heterogeneous appearance, with diffuse hypoechoic regions and in some cases the parenchyma presents hyperechoic feature due to infiltration of inflammatory cells (Ober et al, 2004).

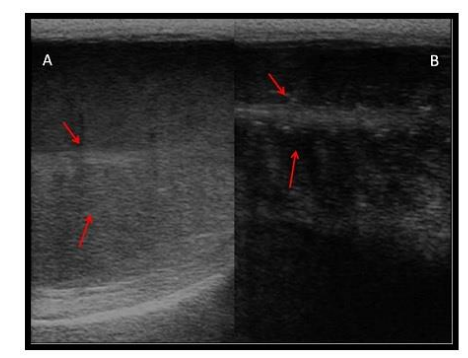

Figure 1. A - Normal testis. The testicular parenchyma is homogeneous with high echogenicity and a hyperechoic mediastinum (arrows). B- Abnormal testis. The testicula parenchyma shows low echogenicity and many hyperechoic spots with few or moderate posterior acoustic shadowing.

\section{Hydrocele}

In this study was diagnosed one $(1.7 \%)$ case of hydrocele. The ultrasound image (Figure 2) shows the presence of a (net) anechoic image between the tunica vaginalis and scrotal skin (hyperechoic line). One the other hand, the testicular parenchyma showed normal echogenicity, as well as the mediastinum.

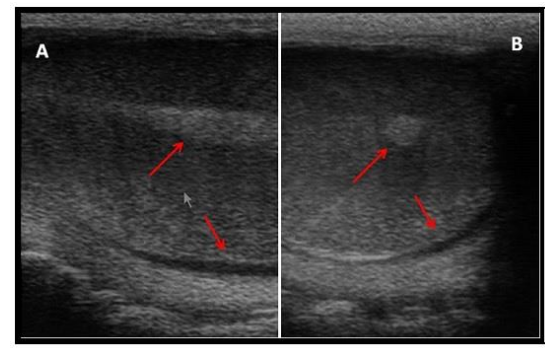

Figure 2. The presence of small amount of fluid between the tunica vaginalis and scrotal skin (longitudinal) and the normal echogenicity of the mediastinum (arrow). B. Small amount of fluid between the tunica vaginalis and scrotal skin (transverse) and the normal echogenicity of the mediastinum (arrow).

Pechman and Eilts (1987) and AbdelRazek and Ali (2005) reported that the coats could only be distinguished by ultrasound, when the presence of liquid occur between the layers, and appeared as more ultrasonic line echogenic than the testicular parenchyma which surrounds the parenchyma, separating it from the scrotum, similar to that found in the present study.

In the same way, Ahmad et al. (1999) described a case of hydrocele in goats, where the affected testes were surrounded by anechoic fluid with hyperechoic fibrin strands within the fluid. Also in other studies (Ahmad et al., 2000), the anechoic areas showed sperm granulomas, which were seen inside the head and tail of the epididymis of infertile rams.

Abu-Seida (2012) studied eight bulls with reproductive problems, and noted in one case of hydrocele in bull of Friesian breed, three years old. Through the ultrasound examination, the scrotal skin appeared as a hyperechoic line clear with anechoic fluid accumulated between the tunica vaginalis and scrotum and both testicles with normal echotexture, echogenicity similar to the result found in the present study.

Thus, it seems hydrocele is a rare disease in bulls raised in the Amazon region, a fact in agreement with the literature consulted. 


\section{Cyst}

During ultrasonographic evaluation, two $(3.4 \%)$ cases of cysts were found in testicular parenchyma measuring $2 \mathrm{~cm}$ long by 2.5 wide (Figure $3)$, which were confirmed after castration (Figure 4) of one of the animals and histopathologic examination (Figure 4).

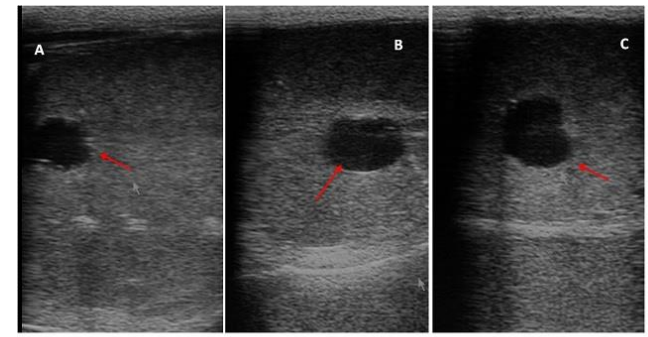

Figure 3. A. Circular anecogenic structure showing well-defined borders slightly irregular (arrow). B. Circular anecogenic structure with well-defined borders (arrow) longitudinal section. C. Circular anecogenic structure with well-defined borders (arrow) cross section.

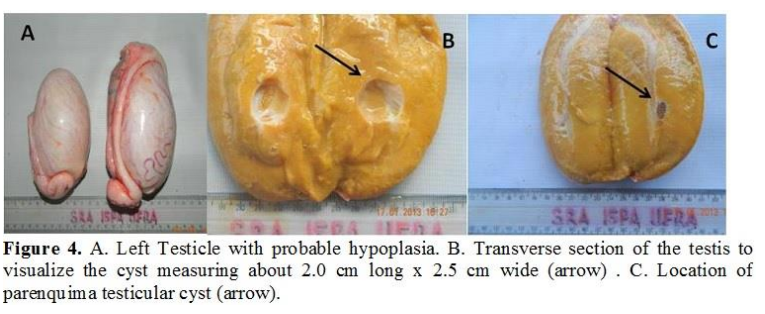

The histopathological examination showed a cystic structure, morphologically characterized by a capsule consisted of dense fibrous connective tissue and the presence of a formation of lobe segments in this process, with a forming a pavement epithelium lining. The testicular tissue adjacent to the cyst shows more developed connective tissue and a lower presence of seminiferous tubules. Many tubules located in this region exhibit absence of germ cells and a thickened basement membrane. Some areas had autolysis with tubular luminal showing flaking and unfoldment of the basement membrane. In other regions there was an increase of connective tissue and atrophy of the seminiferous tubules and sperm presenting espermiostase in some tubules Figure 5. The possible origin of this testicular cyst still continues to be of undefined origin.

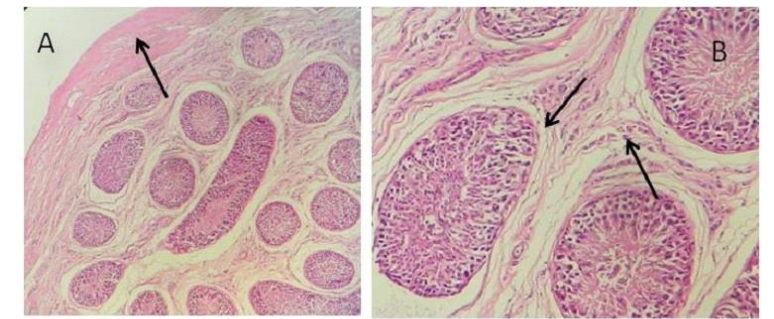

Figure 5 . A. Coated wall of the cyst consists of fibrous capsule of dense connective tissue (arrow ). B. Connective tissue developed further and a lesser presence of seminiferous tubules with total absence of sperms and interstitial area with increasing thickness intertubular (arrows). Bumin et al. (2007) diagnosed by ultrasonography two (5.8\%) cases of intratesticular cysts in dogs. In both studied cases, the cysts had dimensions of $0.8 \times 0.7 \times 0.7 \mathrm{~cm}$ and $0.5 \mathrm{~cm}$ in testucular parenchyma. The cysts showed regular wall with hyperechoic appearance and anaecóica inner region.

Williams et al. (2010) reported one case of cyst in the head of epididymis of a Holstein bull presenting the dorsal pole of the left testis. The epididymis head was absent and was replaced by the presence of a cyst containing clear liquid. The ultrasound exam of this region was characterized by its low echogenicity at the lesion site and presenting approximately $15 \mathrm{~mm}$ in diameter. The histological examination of this type pathology, cells disorder with atypical lining cells, often vacuolated (presumptive of Sertoli cells) and absent spermatogenesis. The head of the left epididymis consisted of an irregular cystic structure, traversed by abundant papillary projections, connective tissue with lymphocytic infiltration with rare sperm.

Moreover Ali et al. (2011) studied ten cases of infertility in buffalo bulls and observed one case of spermatocele (cyst), with the presence of sperm granuloma in the epididymis head. The ultrasound exam of the affected testis showed many anechoic areas within the testis and epididymis, differentiated from the rest of the fabric head by welldefined hyperechoic margins. The lesion with $3.5 \mathrm{~cm}$ diameter, was diagnosed as a cyst (spermatocele), as has been also reported in dogs (England, 1995) and similar to the findings of the present study. 


\section{Testicular degeneration}

During the clinical and ultrasound examination, it was found one (1.7\%) case of testicular degeneration (Figure 6). The mediastinal line showed reduced heterogeneous echogenicity, likely increase the parenchyma showed heterogeneous echogenicity and a small amount of free fluid in the pouch.

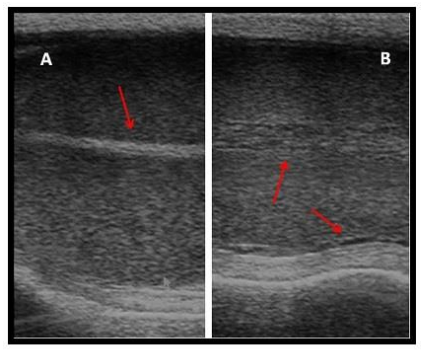

Figure 6. A. Mediastinal line with normal echogenicity (arrow ). B. Mediastinal line with reduced heterogeneous echogenicity, likely increase parenchyma showed heterogeneous echogenicity with small amount of free fluid in the pouch (arrows).

Ahmad et al. (1993) and Ahmad and Noakes (1995 ) observed similar hyperechoic areas in the testicular parenchyma of infertile male goats and being diagnosed as testicular degeneration showing a similar feature as in the present study.

Ali et al. (2011) studied ten cases of infertility in buffalo bulls through ultrasound, and observed six cases of change in ultrasound images, with three cases diagnosed as testicular degeneration. In these tests showed alterations in the consistency and the images showed testes with plenty of hyperechoic areas with acoustic shadowing scattered in the parenchyma. These areas considered as hyperechoic, representing mineralization of the testes (Figure 7). In histopathological examination, these areas were diagnosed as testicular degeneration with mineralization of the seminiferous tubules.

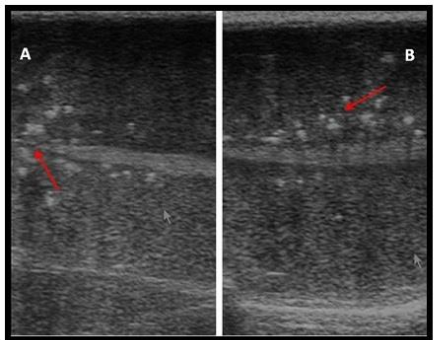

Figure 7 . A. Points of hyperechoic spots with little and moderate posterior acoustic shadowing near mediastinal line (arrow). B. Points hyperechoic with low and moderate formation of acoustic shadow near mediastinal line (arrow).

In a study by Cardilli et al. (2009) in 114 Nelore bulls reared in intensive system, it was reported three animals showed calcification by ultrasound diagnosis however the testis affected did not show any changes in size, shape, position , symmetry, mobility, consistency and sensitivity.

\section{CONCLUSION}

The presence of reproductive diseases in animals submitted to natural mating in the region where conducted this research is still quite high and it seems to be essential to conduct routinely breeding soundness examination (BSE) at regional level.

Also ultrasound seems to be an indispensable tool in the diagnosis of subclinical pathologies of the male reproductive tract, being important for assisting the clinical diagnosis soundness.

\section{REFERENCES}

Abdel-Razek A K and A Ali, 2005. Developmental changes of Bull (Bos taurus) genitália as evaluated by caliper and ultrasonography. Reprod Dom Anim, 40: 23-27.

Abu-Seida A and M Ashraf, 2012. Ultrasonographic diagnosis of some scrotal swellings in bulls. Pak Vet J, 32:378-381.

Ahmad N, DE Noakes, DJ Middleton, 1993. Use of ultrasound to diagnose testicular degeneration in a goat. Vet Rec, 132:36-439. 
Ahmad N and D E Noakes, 1995. A clinical and ultrasonographic study of the testes and related structures of goats and rams after unilateral vasectomy. Vet Rec, 137: 112-117.

Ahmad N, H A Samad, N U Rehman, K M Ahmad, M Ahmad, 1999. An ultrasonographic and histopathological study of the testis and epididymis following experimentally induced unilateral ischemia in male goats and rams. Pak Vet J, 19: 204-209.

Ahmad N, G C W England, D E Noakes, 2000. Ultrasonography of spontaneous lesions of the genital system of three rams, and their influence on semen quality. Vet Rec, 146: 10-15.

Ali K M, N Ahmad, N Akhtar, S Ali, M Ahmad, M Younis, 2011. Ultrasound imaging of testes and epididymides of normal and infertile breeding bulls. Pakistan Veterinary Journal, 31(4): 345350.

Aravindakshan $\mathrm{J} P$, A Hanaramoz, $\mathrm{P} \quad \mathrm{M}$ Bartlewski, 2000. Pattern of gonadotropin secretion and Ultrasonographic evaluation of developmental changes in the testis of early and late maturing bull calves. Theriogenology, 54: 339-354.

Bumin A, M Kaya, U Kaya, M Kibar, Z Alkan, 2007. Gray-scale, colour and power doppler sonography of scrotal disorders in dogs. Revue Méd. Vét.,158 (3): 128-133.

Cardilli D J, G H Toniollo, A A Pastore, J C Canola, M E Z Mercadante, 2009. Alterações do Padrão ultrassonográfico do parênquima testicular em bovinos jovens da raça Nelore, jovens da raça Nelore. Acta Scientiae Veterinariae, 37 (4):367-370.

Cardilli D J, G H Toniollo, A A Pastore, J C Canola, M E Z Mercadante, J A Oliveira, 2010. Padrão ultrassonográfico do parênquima, mediastino e túnicas testiculares em Bovinos Jovens da Raça Nelore. Cien. Anim. Bras, 11 (4): 899-905.

Cardilli D J, G H Toniollo, A A Pastore, J C Canola, J A Oliveira, M E Z Mercadante, 2012. Ultrassonografia testicular em bovinos jovens da raça Nelore criados em sistema extensivo. Arq. Bras. Med. Vet. Zootec., 64(1):75-82.

CBRA. Manual para exame andrológico e avaliação de sêmen animal. 2.ed. Belo Horizonte: Colégio Brasileiro de Reprodução Animal, 1998. 49p.

Cerovsky J A, 1976. New Staining procedure for boar spermatozoa. Zivocisna Vyroba, 21:351362.

Corrêa A B, V R Vale Filho, G S S Corrêa, V J Andrade, M A Silva, J C Dias, 2006.
Características do sêmen e maturidade sexual de touros jovens da raça Tabapuã (Bos taurus indicus) em diferentes manejos alimentares. Arq. Bras. Med. Vet. Zootec., 58(5): 823-830.

England G C, 1995. Ultrasonographic diagnosis of non-palpable Sertoli cell tumours in infertile dogs. J. Small. Anim. Pract.36: 476-80.

Fonseca V O, 2009. Avaliação reprodutiva de touros para monta a campo: análise crítica. Rev. Bras. Reprod. Anim. Supl., 6:36-41.

Henry M, J P Neves, 1998. Manual para exame andrológico e avaliação de sêmen animal. 2.ed. Belo Horizonte: Colégio Brasileiro de Reprodução Animal, 49p.

IBGE - Instituto Brasileiro de Geografia e Estatístca. Produção de pecuária municipal 2011. Disponível em: http://ibge.gov.br. Acesso em: 24 de novembro de 2012.

Kumar S, M C Verma, S S Tripathi, 1988. Comparative Study on Freezability and Effect on Phsicomorfological Characteristics of Murrah Bulls Semen in Different Diluents. Indian Journal Animal Science, 58(7):771-773.

Ober C P, K Spaulding, E B Breitschwerdt, D E Malarkey, B C Hegarty, 2004. Orchitis in two dogs with Rocky Mounta_n spotted fever. Vet. Rad. \& Ultra., 45: 458-465.

Pechman, R D, B E Eilts, 1987. B-mode ultrasonography of the bull testicle. Theriogenology, 27 (2): 431-441.

Rasband W S, 2009. National Institutes of Health, Bethesda, Maryland, USA. Disponível em: < http://rsb.info.nih.gov/ij/, 1997-2009>.

Ribadu A Y, T Nakao, 1999. Bovine reproductive ultrasonography: A review. J. Repr. Dev. 45(1):13-28.

Santos M D, C A A Torres, J R M Ruas, et al., 2004. Potencial reprodutivo de touros da raça Nelore submetidos a diferentes proporções touro:vaca. Arquivo Brasileiro de Medicina Veterinária e Zootecnia, 56(4):497-503.

Statistical Analysis System - SAS. User's guide: Stat. Version 6.11. Cary: SAS Institute, 2000.

Vale W G, 1997. Sperm Cryopreservation. Third Course on Biotechnology of Reproduction In Buffaloes, Caserto, Italy. In: Bubalus bubalis. Journal Buffalo Science and Technique, 4:129 140.

Valentim R, R P Arruda, R C Barnabé, 2002. Biometria testicular de touros Nelore (Bos taurus indicus) e touros cruzados Nelore-europeu (Bos taurus indicus x Bos taurus taurus) aos 20 e 24 meses de idade. Braz. J. Vet. Res. An. Sci., 39(3):113-120. 
Viu M A O, C U Magnabosco, H T Ferraz, M L Gambarini, B D Oliveira Filho, D T Lopes, A M F Viu, 2006. Desenvolvimento ponderal, biometria testicular e qualidade seminal de touros Nelore (Bos taurus indicus) criados extensivamente na região centro-oeste do Brasil. Archives of Veterinary Science, 11: 53-57.

Williams, H. J, S G Revell, S F E Scholes, A E Courtenay, R F Smith, 2010. Clinical, Ultrasonographic and pathological findings in a bull with segmental aplasia of the mesonephric duct. Reprod Dom Anim.,45: 212-216. 